\title{
UNCERTAINTY BUDGET EVALUATION PRINCIPLE IN HIGH AND LOW RESOLUTION DIGITAL MULTIMETERS CALIBRATIONS
}

\author{
Kiril Demerdžiev, Vladimir Dimčev \\ Faculty of Electrical Engineering and Information Technologies, \\ "Ss. Cyril and Methodius" University in Skopje, \\ Rugjer Bošković bb, P.O. box 574, 1001 Skopje, North Macedonia \\ vladim@feit.ukim.edu.mk
}

\begin{abstract}
A b s t r a c t: The main purpose of this paper is definition and mathematical representation of all influencing factors, which can be regarded as uncertainty components in a calibration of both high and low resolutions digital multimeters. The mathematical procedure, which is theoretically proposed is further clarified with a case-study encompassing 2 measurement devices: $6 \frac{1}{2}$ digital and 43/4 digital multimeters. In the case-study, a discussion about the dominant influential factors, regarded as uncertainty components, is provided for both instruments, as well as conclusions about the possibility for neglecting some of them in practical considerations, due to the small impact on the overall budget.
\end{abstract}

Key words: uncertainty component; influential factor; distribution; reference standard; unit under test

\author{
ЕВАЛУАЦИЈА НА БУЏЕТОТ НА МЕРНА НЕОДРЕДЕНОСТ ПРИ КАЛИБРАЦИЈА \\ НА ВИСОКОРЕЗОЛУЦИСКИ И НИСКОРЕЗОЛУЦИСКИ ДИГИТАЛНИ МУЛТИМЕТРИ
}

\begin{abstract}
А п с т р а к т: Примарната цел на овој труд е дефинирање и математичка репрезентација на сите влијателни фактори кои се третираат како компоненти на мерна неодреденост при калибрација на високорезолуциски и нискорезолуциски дигитални мултиметри. Предложената математичка процедура е дополнета со практичен пример, во кој е разработена калибрација на 2 мерни уреда: $6 \frac{1}{2}$ дигитен и $3 \frac{3}{4}$ дигитен мултиметар. Во примерот е презентирана дискусија за доминантните компоненти во буџетот на мерна неодреденост при калибрацијата на двата уреда, како и заклучоци околу можноста за занемарување на дел од нив во практичната евалуација поради минималното влијание врз целокупниот буџет.
\end{abstract}

Клучни зборови: компонента на мерна неодреденост; влијателен фактор; распределба; референтен еталон; уред кој се испитува

\section{INTRODUCTION}

Accredited calibration laboratories [1] conduct periodic examination of instrumentation and measuring systems, in order a continuous traceability chain of any physical quantity to be maintained. An examination procedure consists of comparison between the readings of a device which is subject of a test (Unit Under Test - UUT) and a device of higher accuracy class, which is taken to be a reference standard (RS). The measurements are performed in pre-defined measurement points, which are dictated by international standards or mutual agreement between the laboratory and its clients $[2,3]$.

During calibration, readings of both UUT and RS are recorded and the deviation between those readings in every measurement point is calculated [4]. If the deviation is within the declared accuracy limits, then the UUT can be further used in the same level of the metrological chain where it belonged. If not, corrections, or new specification should be adopted, which will illustrate its current measurement capabilities. 
An important part of the calibration procedure is uncertainty evaluation. Uncertainty is a level of hesitation between the actual measurement result and the true value of a quantity $[5,6]$. In a calibration procedure the uncertainty correlated to the measurement results exists due to several factors of different nature, such as: the declared accuracy of the RS, its long term stability, environmental conditions, etc. [7, 8].

The purpose of this paper is definition and mathematical representation of the components which shape the overall uncertainty budget in calibrations of both high resolution and low resolution digital multimeters. A discussion will be provided about the dominant influential factors in both cases, the distributions adopted for their calculation and the possibility for neglecting some components in practice, due to the small impact on the overall uncertainty budget.

All practical measurements and models presented in the paper are evaluated and developed in Laboratory of Electrical Measurements (LEM), which is part of the Faculty of Electrical Engineering and Information Technologies (FEIT), at Ss. Cyril and Methodius University (UKIM) in Skopje. LEM is an accredited calibration laboratory according to international standard MKS EN ISO/IEC 17025 [1] in domain of electrical quantities and it maintains international traceability to BIPM $[9,10]$.

\section{GENERAL UNCERTAINTY EVALUATION PROCEDURE}

The uncertainty prescribed to the quantity, which is a subject of examination (the measurand), is an interval around the declared or measured value of that quantity, in which its true value lies, with an appropriate probability $[5,6,11]$. If an uncertainty component is about to be expressed and mathematically evaluated, a suitable distribution should be adopted first for representation of the possible values which can be attributed to the quantity itself. According to Guide to the Expression of Uncertainty in Measurement (GUM) [5], uncertainty can be calculated in two ways, using Type A or Type B method of evaluation. According to Type A principle, uncertainty interval is obtained via statistical analysis of the measured data. In other words, several readings for the same measurand are recorded, the result is presented as an arithmetic mean of the $n$ measurements con- ducted and the uncertainty interval is calculated as standard deviation of the mean for the overall measurement data set:

$$
u_{A}=\sqrt{\frac{1}{n(n-1)} \sum_{i=1}^{n}\left(X_{i}-X_{M}\right)^{2}},
$$

where $X_{M}$ is the arithmetic mean calculated from all $n$ single readings, $X_{i}$, performed. The distributions used for this type of evaluation are either Gaussian (Normal) or $t$-distribution, depending primarily on the size of the measurement data set [12].

Uncertainty components evaluated via Type B methodology are obtained by any other means, different than the statistical analysis. Type B evaluation is used predominantly for representing influential factors which are a priori familiar for the measurement performer. Such influential factors may include:

- finite resolution of the instrumentation being used;

- accuracy of the measurement device or a reference standard, presented in a technical datasheet;

- environmental conditions;

- performance of the instrument according to its periodic calibration;

- RS's short and long term stability.

For expression of all these influential factors as uncertainty components, once again, a suitable distribution should be adopted first. When Type B evaluation is conducted, usually one of the geometrical distributions is adopted. If the simplest rectangular (uniform) distribution is used for representing the influential factor, the corresponding Type B uncertainty component is calculated as follows:

$$
u_{B}=\frac{a}{\sqrt{3}},
$$

where $a$ is the half-width of the distribution. On the other hand, if a triangular distribution is adopted, the uncertainty component equals:

$$
u_{B}=\frac{a}{\sqrt{6}},
$$

where $a$ possess the same meaning as described above. Triangular distribution is used when there is a higher probability for a measurement result to lie close to the mean value. For Type B evaluation, Gaussian distribution can be adopted as well. 
In many practical examples, there are several influential factors that affect one measurement procedure. Those influential factors can be mathematically expressed as uncertainty components by using Type A and Type B methods of evaluation which were previously discussed. The overall uncertainty prescribed to the measured quantity is than calculated as standard combined uncertainty, regarding all the input components as mutually uncorrelated, which is, in many practical cases, a correct assumption:

$$
u_{C}=\sqrt{\sum_{i=1}^{m}\left(\frac{\partial Y}{\partial X_{i}} \cdot u_{i}\right)^{2}},
$$

where $Y=f\left(X_{1}, X_{2}, \ldots X_{m}\right)$ is a mathematical function which combines all $m$ influencing factors, represented as input quantities, and $u_{i}$ are the single uncertainty components.

According to [5], the overall uncertainty, presented in a measurement report, should correspond to a probability of $95 \%$ or more. It is called expanded uncertainty and is obtained by multiplying the value obtained according to (4) with a coverage factor, $k[5,6]$. The coverage factor depends on the distribution prescribed to the measurand, when all single influencing factors are taken into account. If several influencing factors affect the measurement procedure, than according to the Central Limit Theorem $[5,6]$, the overall distribution is taken to be Normal, nevertheless the distributions adopted for single uncertainty components evaluation. In such a scenario, a coverage factor $k=2$ is used for calculating the combined uncertainty, which corresponds to a $95.4 \%$ confidence interval, according to Gaussian (Normal) distribution:

$$
U_{C}=k \cdot u_{C}=2 \cdot u_{C} \cdot
$$

\section{MEASUREMENT EQUIPMENT AND UNCERTAINTY EVALUATION PROCEDURE}

As it was mentioned in the introduction of the paper, examination of 2 measurement devices, a high resolution and a low resolution digital multimeters will be conducted. The first instrument is a 61/2 digital multimeter, FLUKE 8846 A [13], while the second is MASTECH MS 8218, a $43 / 4$ digit True RMS multimeter [14], both in possession of LEM. The role of a reference standard is played by LEM's secondary (working) standard in domain of three phase low frequency voltages and currents, electrical power and energy, CALMET C300 [15]. CALMET C300 is a three phase signal generator, of accuracy class $0.02 \%$, for currents and voltages above $10 \%$ and $30 \%$ of its current and voltage measurement ranges respectively.

For the calibration procedure, a total of 6 measurement points, from which 3 belong to the $\mathrm{AC}$ voltage measurement mode and 3 belong to the AC current measurement mode, were chosen. In Figure 1, the connection of an instrument to the current and voltage terminals of C300 is illustrated.

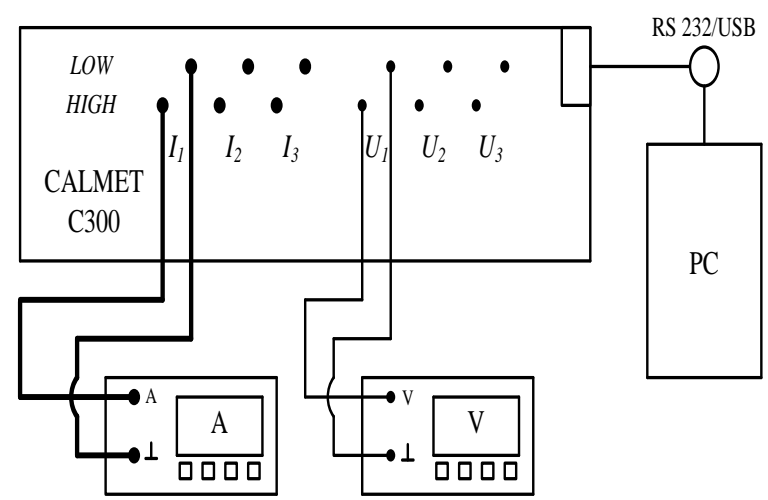

Fig. 1. Connection for voltage and current ranges calibration

In Table 1, the specification required for calibration of FLUKE 8846 A, obtained from its technical datasheet [13] is presented. The same data, for the low resolution UUT is presented in Table 2. In the third column of both Tables 1 and 2, the declared accuracy by the manufacturer is illustrated. For the high resolution instrument it is presented in the following format:

$$
a c c=E_{R V(\%)}+E_{M R(\%)},
$$

where $E_{R V(\%)}$ is a part of the error corresponding to the read value, while $E_{M R(\%)}$ is part of the error corresponding to measuring range.

Table 1

Specifications of FLUKE 8846 A

\begin{tabular}{cccr}
\hline $\begin{array}{c}\text { Measurement } \\
\text { range }\end{array}$ & $\begin{array}{c}\text { Measurement } \\
\text { point }\end{array}$ & $\begin{array}{c}\text { Declared accura- } \\
\text { cy,acc (\%) }\end{array}$ & $\begin{array}{c}\text { Resolution, } \\
\text { res }\end{array}$ \\
\hline $10 \mathrm{~V}$ & $5 \mathrm{~V}$ & $0.06 \%+0.03$ & $0.00001 \mathrm{~V}$ \\
$100 \mathrm{~V}$ & $100 \mathrm{~V}$ & $0.06 \%+0.03$ & $0.0001 \mathrm{~V}$ \\
$1000 \mathrm{~V}$ & $230 \mathrm{~V}$ & $0.06 \%+0.03$ & $0.001 \mathrm{~V}$ \\
$1 \mathrm{~A}$ & $0.5 \mathrm{~A}$ & $0.1 \%+0.04$ & $0.000001 \mathrm{~A}$ \\
$1 \mathrm{~A}$ & $1 \mathrm{~A}$ & $0.1 \%+0.04$ & $0.000001 \mathrm{~A}$ \\
$10 \mathrm{~A}$ & $5 \mathrm{~A}$ & $0.15 \%+0.06$ & $0.00001 \mathrm{~A}$ \\
\hline \hline
\end{tabular}


Table 2

\section{Specifications of MASTECH MS 8218}

\begin{tabular}{cccc}
\hline $\begin{array}{c}\text { Measurement } \\
\text { range }\end{array}$ & $\begin{array}{c}\text { Measurement } \\
\text { point }\end{array}$ & $\begin{array}{c}\text { Declared accuracy, } \\
\text { acc (dig) }\end{array}$ & $\begin{array}{c}\text { Resolution, } \\
\text { res }\end{array}$ \\
\hline $5 \mathrm{~V}$ & $5 \mathrm{~V}$ & $0.5 \%+40$ & $0.0001 \mathrm{~V}$ \\
$500 \mathrm{~V}$ & $100 \mathrm{~V}$ & $0.5 \%+40$ & $0.01 \mathrm{~V}$ \\
$500 \mathrm{~V}$ & $230 \mathrm{~V}$ & $0.5 \%+40$ & $0.01 \mathrm{~V}$ \\
$500 \mathrm{~mA}$ & $500 \mathrm{~mA}$ & $0.75 \%+10$ & $0.01 \mathrm{~mA}$ \\
$5 \mathrm{~A}$ & $1 \mathrm{~A}$ & $0.75 \%+20$ & $0.0001 \mathrm{~A}$ \\
$5 \mathrm{~A}$ & $5 \mathrm{~A}$ & $0.75 \%+20$ & $0.0001 \mathrm{~A}$ \\
\hline \hline
\end{tabular}

Both $E_{R V(\%)}$ and $E_{M R(\%)}$ are expressed as percentage values. For MASTECH MS 8218 the declared accuracy is presented in the following pattern:

$$
a c c=E_{R V(\%)}+E_{d i g},
$$

where $E_{R V(\%)}$ possess the same meaning as in (6), while $E_{d i g}$ is a part of the error expressed as a full time the value of the Least Significant Digit (resolution).

For every measurement point, in both calibration procedures, a total of 10 readings, $X_{i}$, are recorded. Those readings are obtained in $15 \mathrm{~s}$ intervals. The arithmetic mean of the measurements is then calculated and it is regarded as the best approximation of the UUT's measured value:

$$
X_{U U T}=X_{M}=\frac{1}{10} \sum_{i=1}^{10} X_{i} .
$$

The deviation between the applied value by the RS and UUT's reading is then calculated as:

$$
\Delta X=X_{U U T}-X_{R S} \text {. }
$$

The uncertainty prescribed to the calibration procedure comprises of 6 mutually uncorrelated components. The first one is a result of the measurement results' repeatability. When high resolution instrumentation is a subject of examination, a scattering of the single readings around the mean value is expected. Because several (in the concrete procedure 10) measurements are recorded for every measurement point, the repeatability related uncertainty component is calculated according to Type A evaluation, using (1) and statistical analysis.

The second factor for uncertainty existence is UUT's finite resolution. This component is calculated assuming rectangular distribution with a mean value equal to the UUT's reading and a half- width equal to half the resolution. The resolution, for different measurement points, for the 2 devices, is illustrated in Tables 1 and 2. Taking all forementioned conclusions into account, this uncertainty component is calculated as follows:

$$
u_{R E S}=\frac{r e s}{2 \cdot \sqrt{3}} .
$$

The third uncertainty component is correlated to the declared accuracy of the RS. Namely, for the concrete performance, CALMET C300 plays the role of a reference standard and the data necessary for this uncertainty component calculation is found in its technical datasheet [15]. As it was mentioned earlier, the declared accuracy of the RS equals 0.02 $\%$ for both current and voltage measurements. This information, however, is an expanded uncertainty, expressed in a percentage form, so in order a standard value to be obtained, some basic mathematical expressions should be implemented. In [15], it is stated that the declared accuracy corresponds to a $95 \%$ confidence interval, according to Normal distribution. In order a standard percentage form to be obtained, the specification data is supposed to be divided by coverage factor of 1.96 .

$$
u_{A C C(\%)}=\frac{U_{A C C(\%)}}{1.96}=\frac{0.02}{1.96}=0.0102 \% \text {. }
$$

Because all other uncertainty components are expressed as absolute values, (11) must be transformed in the same form either:

$$
u_{A C C}=\frac{u_{A C C(\%)}}{100} \cdot X_{R S}=1.02 \cdot 10^{-4} \cdot X_{R S},
$$

where $X_{R S}$ is the applied value, i.e. the value read from the reference standard.

The next two influencing factors are once again obtained from the technical datasheet of the reference standard [15]. RS's long term stability is a reason for the fourth uncertainty component existence. For voltage and current measurements, the declared long term stability equals $0.01 \%$ per 1 year. Because in the moment of writing of this paper, the last calibration of the reference standard is within the 1 year period, this uncertainty is equal to $0.01 \%$, for both the current and voltage measurements. Once again, it is presented as expanded percentage uncertainty and a Normal distribution is prescribed with a probability rate of $95 \%$. The value obtained from [15] has to be converted, from relative (percentage), into a standard absolute form: 


$$
u_{S T}=\frac{U_{S T(\%)}}{1.96 \cdot 100} \cdot X_{R S}=5.102 \cdot 10^{-5} \cdot X_{R S}
$$

Temperature influence on the RS's performance is a reason for the fifth uncertainty component existence. In [15] it is stated that this uncertainty component equals $0.0005 \%$ for both current and voltage measurements for every $1{ }^{\circ} \mathrm{C}$, in the interval between of $20{ }^{\circ} \mathrm{C}$ and $26{ }^{\circ} \mathrm{C}$. Because all the measurements were conducted in a temperature controlled environment, within these boundaries, this uncertainty component will be calculated as three times the declared value $\left(23 \pm 3{ }^{\circ} \mathrm{C}\right)$ :

$$
u_{T E M P}=\frac{3 \cdot U_{T E M P(\%)}}{1.96 \cdot 100} \cdot X_{R S}=7.653 \cdot 10^{-6} \cdot X_{R S} .
$$

The absolute standard uncertainty component $u_{T E M P}$, calculated with (14) is once again obtained assuming Normal distribution and probability rate of $95 \%$, as stated in [15].

The last uncertainty component is obtained from the calibration certificate of the RS itself, in other words, its existence is due to the traceability in the level up calibrations. For voltage measurements, the calculated calibration uncertainty equals $\pm 0.006 \%$, while for current measurements, it equals $\pm 0.0095 \%$. Once again, this uncertainty component, nevertheless current or voltage based, is expressed in a percentage form, with a confidence interval of $95.4 \%$ (coverage factor $k=2$ ) according to Gaussian distribution. In order an absolute standard value to be obtained, some mathematical modifications are supposed to take place:

$$
u_{C A L}=\frac{U_{C A L(\%)}}{2 \cdot 100} \cdot X_{R S} .
$$

The overall uncertainty prescribed to the calibration procedure is calculated via equation (4), taking all the influencing factors as mutually uncorrelated. Additionally, all the sensitivity coefficients $\left(\partial Y / \partial X_{i}\right)$ are taken as unity, because all uncertainty components are in the same unit as the measured quantity and they contribute equally to the overall budget. Taking all this into account, the combined uncertainty equals:

$$
u_{C}=\sqrt{u_{R E P}^{2}+u_{R E S}^{2}+u_{A C C}^{2}+u_{S T}^{2}+u_{T E M P}^{2}+u_{C A L}^{2}}
$$

In the calibration certificate, the overall uncertainty is presented as expanded uncertainty, with a $95.4 \%$ probability rate, according to Normal distribution, (5).

\section{HIGH RESOLUTION MULTIMETER CALIBRATION}

As was mentioned in the previous chapter of this work, the first part of the case study encompass examination of a $6 \frac{1}{2}$ digital multimeter, FLUKE $8846 \mathrm{~A}$, in 6 measurement points, from which 3 belong to the $\mathrm{AC}$ voltage measurement mode and 3 belong to the $\mathrm{AC}$ current measurement mode. In every measurement point, a total of 10 readings are recorded and the arithmetic mean value is calculated as the best representation of UUT's performance. All the measurements are performed in a temperature and humidity controlled environment. The temperature was within the interval of $23 \pm 3{ }^{\circ} \mathrm{C}$, as required by the specification of the RS. The relative humidity was below $55 \%$ in any moment during the calibration procedure. Also, according to the instructions in [15], the RS was warmed up $2 \mathrm{~h}$ before the procedure was commenced.

The single measurements recorded with FLUKE $8846 \mathrm{~A}$ are illustrated in Table 3 . The previously discussed approach for determination of uncertainty components, will be practically performed. It means that the repeatability of the measurements is going to be evaluated as Type A uncertainty, and all other influencing factors are going to be regarded as Type B uncertainties, as was described in details in the previous chapter, by presentation of mathematical model which encompassed equations (10) to (15). All uncertainty component values, for the 6 previously chosen measurement points, are illustrated in Table 4 .

Table 3

\begin{tabular}{cccccc}
\multicolumn{7}{c}{ Readings of FLUKE 8846A } \\
\hline \hline \multicolumn{7}{c}{ Measurement point } \\
\hline $5 \mathrm{~V}$ & $100 \mathrm{~V}$ & $230 \mathrm{~V}$ & $0.5 \mathrm{~A}$ & $1 \mathrm{~A}$ & $5 \mathrm{~A}$ \\
\hline \multicolumn{7}{c}{ Readings } \\
\hline$V_{i}[\mathrm{~V}]$ & $V_{i}[\mathrm{~V}]$ & $V_{i}[\mathrm{~V}]$ & $I_{i}[\mathrm{~A}]$ & $I_{i}[\mathrm{~A}]$ & $I_{i}[\mathrm{~A}]$ \\
\hline 4.99584 & 99.8912 & 229.78 & 0.500049 & 1.000049 & 4.99854 \\
4.99573 & 99.8912 & 229.779 & 0.500071 & 0.99997 & 4.99862 \\
4.99559 & 99.8915 & 229.782 & 0.499752 & 0.999793 & 4.99864 \\
4.99562 & 99.891 & 229.786 & 0.499767 & 0.999747 & 4.99874 \\
4.99582 & 99.8913 & 229.788 & 0.499942 & 1.000089 & 4.99882 \\
4.99589 & 99.8919 & 229.784 & 0.500076 & 0.999904 & 4.99894 \\
4.9958 & 99.8913 & 229.782 & 0.500086 & 0.99982 & 4.99887 \\
4.99575 & 99.8904 & 229.78 & 0.499909 & 0.999935 & 4.99876 \\
4.99573 & 99.8899 & 229.782 & 0.499752 & 1.000069 & 4.99884 \\
4.99561 & 99.8903 & 229.784 & 0.49982 & 0.999966 & 4.99907 \\
\hline \hline
\end{tabular}


Table 4

Uncertainty evaluation in FLUKE 8846 A

\begin{tabular}{rrrrrrrr}
\hline \hline \multirow{2}{*}{$\begin{array}{c}\text { Measuring } \\
\text { point }\end{array}$} & \multicolumn{1}{c}{$\begin{array}{c}\text { Repeatability, } \\
u_{A}\end{array}$} & $\begin{array}{c}\text { Resolution, } \\
u_{R E S}\end{array}$ & $\begin{array}{c}\text { RS accuracy, } \\
u_{A C C}\end{array}$ & $\begin{array}{c}\text { RS stability, } \\
\text { uST }\end{array}$ & $\begin{array}{r}\text { Temperature drift, } \\
u_{T E M P}\end{array}$ & $\begin{array}{c}\text { Traceability, } \\
u_{C A L}\end{array}$ \\
\hline $5 \mathrm{~V}$ & $32.76 \cdot 10^{-6} \mathrm{~V}$ & $2.89 \cdot 10^{-6} \mathrm{~V}$ & $0.00051 \mathrm{~V}$ & $0.000255 \mathrm{~V}$ & $38.265 \cdot 10^{-6} \mathrm{~V}$ & $0.00015 \mathrm{~V}$ \\
$100 \mathrm{~V}$ & $193.79 \cdot 10^{-6} \mathrm{~V}$ & $28.87 \cdot 10^{-6} \mathrm{~V}$ & $0.010204 \mathrm{~V}$ & $0.005102 \mathrm{~V}$ & $765.306 \cdot 10^{-6} \mathrm{~V}$ & $0.003 \mathrm{~V}$ \\
$230 \mathrm{~V}$ & $895.05 \cdot 10^{-6} \mathrm{~V}$ & $288.67 \cdot 10^{-6} \mathrm{~V}$ & $0.0235 \mathrm{~V}$ & $0.011735 \mathrm{~V}$ & $1760.204 \cdot 10^{-6} \mathrm{~V}$ & $0.0069 \mathrm{~V}$ \\
$0.5 \mathrm{~A}$ & $44.94 \cdot 10^{-6} \mathrm{~A}$ & $0.29 \cdot 10^{-6} \mathrm{~A}$ & $0.000051 \mathrm{~A}$ & $0.0000255 \mathrm{~A}$ & $3.8265 \cdot 10^{-6} \mathrm{~A}$ & $0.0000238 \mathrm{~A}$ \\
$1 \mathrm{~A}$ & $37.50 \cdot 10^{-6} \mathrm{~A}$ & $0.29 \cdot 10^{-6} \mathrm{~A}$ & $0.000102 \mathrm{~A}$ & $0.000051 \mathrm{~A}$ & $7.653 \cdot 10^{-6} \mathrm{~A}$ & $0.0000475 \mathrm{~A}$ \\
$5 \mathrm{~A}$ & $50.29 \cdot 10^{-6} \mathrm{~A}$ & $2.89 \cdot 10^{-6} \mathrm{~A}$ & $0.00051 \mathrm{~A}$ & $0.000255 \mathrm{~A}$ & $38.265 \cdot 10^{-6} \mathrm{~A}$ & $0.000238 \mathrm{~A}$ \\
\hline \hline
\end{tabular}

The general conclusion about the single uncertainty components, illustrated in Table 4 , is that each individual factor contributes with different share in the overall budget. The highest uncertainty value, for the concrete examination procedure, is correlated to the RS's declared accuracy. This uncertainty component, having a Normal distribution, shapes dominantly the overall distribution as well. It is between 2 and 4 times bigger than the influencing factors correlated to the standard's long term stability and level up calibration. These two uncertainty components' values, obtained also by assuming Normal distribution, are of the same order of magnitude for every measurement point. Because the previously mentioned three components are correlated to the reference standard's value, it is obvious that in high resolution instrumentation calibrations, the performance of the RS plays significant and dominant role in the definition of the overall uncertainty budget.

The temperature drift component is highly dependent on the temperature fluctuations and in an environment where a continuous temperature monitoring is conducted, it is approximately 10 times lower than the RS's stability related component. This uncertainty can be further reduced if there is a more strict temperature control, in a smaller interval, for example $23 \pm 1{ }^{\circ} \mathrm{C}$.

As can be seen from Table 4, the lowest uncertainties, in this type of electrical calibrations, are correlated to the performance and specification of the UUT. This conclusion is predominantly attributed to the meter's resolution, which is the lowest influencing factor for every measurement point. In many practical considerations, this uncertainty can be neglected, because if more repeated measurements are made, the average value usually extends over the resolution of the instrumentation.
On the other hand, repeatability related uncertainty component is strongly dependent on the fluctuations of the single readings around the mean value. For the concrete calibration procedure, in case of voltage measurements, single reading fluctuations are not generating uncertainty which contributes significantly in the overall uncertainty budget. That is, however, not the case for the current readings, especially for $0.5 \mathrm{~A}$ and $1 \mathrm{~A}$ measurement points.

As can be seen from Table 4, for these 2 measurement points, Type A uncertainty possess a value which is the same order of magnitude as the stability and traceability related components. The same conclusion can be reached if the single readings in Table 3 are observed. In these measurement points, the readings' repeatability influence is higher than the temperature change effect on the RS's performance. All these conclusions will be further backed up with the analysis that follows

In Table 5, the combined uncertainty for every measurement point is calculated according to the principles suggested in GUM [5] and by applying (4). In the second column of the table, the overall uncertainty is calculated taking all 6 influential factors into account, as suggested in (16). The values presented in the last column of Table 5, are obtained by neglecting some of the smaller influencing factors, namely the components related to the UUT. All values are rounded on two significant digits, as proposed in [8].

From Table 5 it can be once again concluded that in measurement points where no significant dispersion of single readings is present, statistical analysis of measurement data is insignificant for the overall uncertainty budget. However in those measurement points where significant fluctuations between the readings are noticed, Type A uncer- 
tainty possess a value comparable to other uncertainty components and have to be included in the overall data set.

Table 5

Combined uncertainty with and without UUT related components

\begin{tabular}{crc}
\hline \hline $\begin{array}{c}\text { Measurement } \\
\text { point }\end{array}$ & $\begin{array}{c}\text { Combined uncertainty } \\
\text { with UUT related } \\
\text { components }\end{array}$ & $\begin{array}{c}\text { Combined uncertainty } \\
\text { without UUT related } \\
\text { components }\end{array}$ \\
\hline $5 \mathrm{~V}$ & $0.00059 \mathrm{~V}$ & $0.00059 \mathrm{~V}$ \\
$100 \mathrm{~V}$ & $0.012 \mathrm{~V}$ & $0.012 \mathrm{~V}$ \\
$230 \mathrm{~V}$ & $0.027 \mathrm{~V}$ & $0.027 \mathrm{~V}$ \\
$0.5 \mathrm{~A}$ & $0.000076 \mathrm{~A}$ & $0.000062 \mathrm{~A}$ \\
$1 \mathrm{~A}$ & $0.00013 \mathrm{~A}$ & $0.00012 \mathrm{~A}$ \\
$5 \mathrm{~A}$ & $0.00062 \mathrm{~A}$ & $0.00062 \mathrm{~A}$ \\
\hline \hline
\end{tabular}

In Table 6, the complete calibration data is presented. It can be seen that for every measurement point the calculated error plus the declared uncertainty is within the declared accuracy limits. That means that the concrete instrument, FLUKE $8846 \mathrm{~A}$ can be further used in the same place of the metrological chain where it belongs, according to its specification.

Table 6

Overall calibration data set for FLUKE 8846 A

\begin{tabular}{cccc}
\hline $\begin{array}{c}\text { Measurement } \\
\text { point }\end{array}$ & Error, & $\begin{array}{c}\text { Expanded } \\
\text { uncertainty, } \\
U_{C}\end{array}$ & $\begin{array}{c}\text { Accuracy } \\
\text { limits, } \\
a c c\end{array}$ \\
\hline $5 \mathrm{~V}$ & $-0.0043 \mathrm{~V}$ & $\pm 0.0012 \mathrm{~V}$ & $\pm 0.006 \mathrm{~V}$ \\
$100 \mathrm{~V}$ & $-0.11 \mathrm{~V}$ & $\pm 0.024 \mathrm{~V}$ & $\pm 0.09 \mathrm{~V}$ \\
$230 \mathrm{~V}$ & $-0.22 \mathrm{~V}$ & $\pm 0.054 \mathrm{~V}$ & $\pm 0.44 \mathrm{~V}$ \\
$0.5 \mathrm{~A}$ & $-0.000078 \mathrm{~A}$ & $\pm 0.00015 \mathrm{~A}$ & $\pm 0.0009 \mathrm{~A}$ \\
$1 \mathrm{~A}$ & $-0.000066 \mathrm{~A}$ & $\pm 0.00026 \mathrm{~A}$ & $\pm 0.0014 \mathrm{~A}$ \\
$5 \mathrm{~A}$ & $-0.0012 \mathrm{~A}$ & $\pm 0.0012 \mathrm{~A}$ & $\pm 0.0135 \mathrm{~A}$ \\
\hline \hline
\end{tabular}

\section{LOW RESOLUTION MULTIMETER CALIBRATION}

The second part of the case study is the implementation of the same mathematical model for uncertainty evaluation, but this time on a low resolution measurement device. The UUT in this particular case is a $4 \frac{3}{4}$ digital multimeter MASTECH
MS 8218 and the examination was conducted in the same 6 measurement points. Once again 10 readings were recorded, and all the measurements were conducted in a temperature and humidity controlled environment.

According to the model for uncertainty evaluation, presented in the third chapter of the work, the uncertainty components can be divided into three sub-groups: UUT, RS's specification and traceability related components. The influencing factors correlated to the RS's performance and traceability in measurements, are dependent on the applied value, $X_{R S}$, so they are the same nevertheless the type of the UUT. All these uncertainties are presented in Table 4.

On the other hand the remaining two components are dependent on the specification and behavior of the UUT. The readings made by MASTECH MS8218 are presented in Table 7, while its repeatability and resolution related uncertainties are illustrated in Table 8.

From Tables 4 and 8, a comparison between the values of single uncertainty components can be evaluated. For the $0.5 \mathrm{~A}$ point all uncertainties in Table 4 has to be multiplied by 1000 , in order a $\mathrm{mA}$ values, the same as UUT's reading, to be obtained. It can be concluded that the RS's accuracy is still the highest uncertainty component, except for the $5 \mathrm{~V}$ measurement point, where high fluctuations between the single measurements are recorded, i.e. significant Type A component is present.

Table 7

Readings of MASTECH MS8218

\begin{tabular}{cccccc}
\hline \hline \multicolumn{7}{c}{ Measurement point } \\
\hline $5 \mathrm{~V}$ & $100 \mathrm{~V}$ & $230 \mathrm{~V}$ & $500 \mathrm{~mA}$ & $1 \mathrm{~A}$ & $5 \mathrm{~A}$ \\
\hline \multicolumn{7}{c}{ Readings } \\
\hline$V_{i}(\mathrm{~V})$ & $V_{i}(\mathrm{~V})$ & $V_{i}(\mathrm{~V})$ & $I_{i}(\mathrm{~mA})$ & $I_{i}(\mathrm{~A})$ & $I_{i}(\mathrm{~A})$ \\
\hline 4.9855 & 100.09 & 230.35 & 499.43 & 0.9997 & 4.9929 \\
4.9861 & 100.09 & 230.37 & 499.44 & 0.9999 & 4.9926 \\
4.9860 & 100.09 & 230.38 & 499.41 & 1.0001 & 4.9925 \\
4.9904 & 100.10 & 230.36 & 499.42 & 1.0002 & 4.9924 \\
4.9872 & 100.11 & 230.37 & 499.42 & 1.0001 & 4.9926 \\
4.9889 & 100.12 & 230.37 & 499.43 & 1.0000 & 4.9927 \\
4.9925 & 100.11 & 230.36 & 499.42 & 0.9998 & 4.9924 \\
4.9934 & 100.10 & 230.37 & 499.43 & 0.9999 & 4.9926 \\
4.9902 & 100.10 & 230.37 & 499.43 & 1.0001 & 4.9925 \\
4.9866 & 100.09 & 230.38 & 499.43 & 1.0002 & 4.9924 \\
\hline \hline
\end{tabular}


Table 8

Repeatability and resolution related uncertainties for MASTECH MS 8218

\begin{tabular}{rcc}
\hline \hline $\begin{array}{c}\text { Measurement } \\
\text { point }\end{array}$ & $\begin{array}{c}\text { Repeatability } \\
\text { related uncertainty }\end{array}$ & $\begin{array}{c}\text { Resolution } \\
\text { related uncertainty }\end{array}$ \\
\hline $5 \mathrm{~V}$ & $0.001271 \mathrm{~V}$ & $0.000029 \mathrm{~V}$ \\
$100 \mathrm{~V}$ & $0.004714 \mathrm{~V}$ & $0.002896 \mathrm{~V}$ \\
$230 \mathrm{~V}$ & $0.00411 \mathrm{~V}$ & $0.00289 \mathrm{~V}$ \\
$500 \mathrm{~mA}$ & $0.003771 \mathrm{~mA}$ & $0.00289 \mathrm{~mA}$ \\
$1 \mathrm{~A}$ & $0.000076 \mathrm{~A}$ & $0.000029 \mathrm{~A}$ \\
$5 \mathrm{~A}$ & $0.000071 \mathrm{~A}$ & $0.000029 \mathrm{~A}$ \\
\hline \hline
\end{tabular}

For all other measurement points, the repeatability related uncertainty is the same order of magnitude as RS's stability and traceability components. This means that, in this particular case Type A uncertainty cannot be neglected in the calculation of the combined and expanded uncertainty. The same conclusion can be derived for the resolution as an influencing factor, that in low resolution instrumentation calibrations this component is as significant as the long term stability uncertainty.

Table 9

Overall calibration data set for MASTECH MS8218

\begin{tabular}{cccc}
\hline $\begin{array}{c}\text { Measurement } \\
\text { point }\end{array}$ & Error, & $\begin{array}{c}\text { Expanded } \\
\text { uncertainty, } \\
U_{C}\end{array}$ & $\begin{array}{c}\text { Accuracy lim- } \\
\text { its, } \\
\text { acc }\end{array}$ \\
\hline $5 \mathrm{~V}$ & $-0.011 \mathrm{~V}$ & $\pm 0.0028 \mathrm{~V}$ & $\pm 0.029 \mathrm{~V}$ \\
$100 \mathrm{~V}$ & $0.10 \mathrm{~V}$ & $\pm 0.026 \mathrm{~V}$ & $\pm 0.90 \mathrm{~V}$ \\
$230 \mathrm{~V}$ & $0.37 \mathrm{~V}$ & $\pm 0.055 \mathrm{~V}$ & $\pm 1.55 \mathrm{~V}$ \\
$500 \mathrm{~mA}$ & $-0.57 \mathrm{~mA}$ & $\pm 0.12 \mathrm{~mA}$ & $\pm 3.85 \mathrm{~mA}$ \\
$1 \mathrm{~A}$ & $0 \mathrm{~A}$ & $\pm 0.00030 \mathrm{~A}$ & $\pm 0.0095 \mathrm{~A}$ \\
$5 \mathrm{~A}$ & $-0.0074 \mathrm{~A}$ & $\pm 0.0012 \mathrm{~A}$ & $\pm 0.039 \mathrm{~A}$ \\
\hline \hline
\end{tabular}

In Table 9 the overall calibration data set is presented. Once again, the measurement error along with the prescribed uncertainty is within the declared accuracy limits of the UUT, which means that this instrument can be further used in the same place of the metrological traceability chain where the concrete requirements for accuracy are sufficient.

\section{CONCLUSION}

In the paper, an examination of $61 / 2$ and $43 / 4$ digital multimeters, with a reference standard of higher accuracy class, is conducted. Mathematical model for uncertainty evaluation is presented, which is developed and used in practical calibration performances in LEM.

The overall uncertainty budget consists of 6 mutually uncorrelated influencing components. They exist because of the repeatability of measurement readings and finite resolution of UUT; accuracy, long term stability and temperature influence of the RS; as well as a single component correlated to the measurement traceability. Each single uncertainty component contributes with different share in the overall uncertainty budget.

In high resolution instrumentation calibrations the dominant factor in the overall uncertainty budget is the declared accuracy of the RS. The other components correlated to the RS are several times smaller than the accuracy related component, while the last 2 uncertainties, correlated to the UUT's resolution and repeatability of readings, in many practical considerations can be neglected, because of the small impact on the overall budget.

On the other hand, in low resolution calibretions these 2 components contribute with significant share in the overall uncertainty budget. Their values can be compared to the values related to the RS's performance and traceability in measurements. In some measurement points where high fluctuations between the readings are present, the Type A uncertainty is the dominant component, which shapes the overall budget.

\section{REFERENCES}

[1] EN ISO/IEC 17025: General Requirements for the Competence of Testing and Calibration Laboratories, Cenelec, Brussels, 2005.

[2] EURAMET cg-15: Guidelines on the Calibration of Digital Multimeters, Ver. 3 02/2015.

[3] RU 5.4. 01: Working Instruction on Calibration of Multimeters, LEM-FEIT, 2015.

[4] Calibration-Phylosophy in Practice. Fluke Cooperation, Second Edition, 1994.

[5] Evaluation of measurement data - Guide to the expression of uncertainty in measurement (GUM), JCGM 100 with member organizations (BIPM, IEC, IFCC, ILAC, ISO, IUPAC, IUPAP and OIML), 2008.

[6] Osmanović, P., Stanković, K., Vujisić, M.: Measurement Uncertainty, Akademska Misao, Belgrade, 2009. 
[7] RU 5.4. 04: Working Instruction on Expression of Measurement Uncertainty - General Procedure, LEM-FEIT, 2015.

[8] EA-4/02: Expressions of the Uncertainty of Measurements in Calibration (previously EALR2), 2013.

[9] Demerdžiev, K., Čundeva-Blajer, M., Dimčev, V., Srbinovska, M., Kokolanski, Ž.: Improvement of the FEIT Laboratory of Electrical Measurements Best CMC through Internationally Traceable Calibrations and InterLaboratory Comparisons, XIV International Conference ETAI, Struga, September 2018.

[10] Demerdžiev, K., Čundeva-Blajer, M., Dimčev, V., Srbinovska, M., Kokolanski, Ž.: Defining an uncertainty budget in electrical power and energy reference standards calibration, IEEE Eurocon, Novi Sad, Serbia, July 2019.

[11] UKAS M3003: The expression of uncertainty and confidence in measurements, 2006.

[12] Gavrovski, C., Basic of Measurement Technics, Second edition, Faculty of Electrical Engineering and Information Technologies, Skopje, 2011.
[13] FLUKE 8845 A/8846: A user's manuel, Fluke corporation, July 2006.

[14] MASTECH MS8218: User Manual, Mastech corporation.

[15] CALMET 300: Three Phase Power Calibrator and Power Engineering Apparatus Testing User's manual, Calmet Ltd., Poland, 2013-01.

[16] Čndeva-Blajer, M.: Analysis of the State of the Art with Contribution to the Metrology Infrastructure through Accredited and Traceable Measurements of Electrical Power and Energy, Proceedings of the International Symposium "Energetics" 2016, Ohrid, R. Macedonia, 6-8 October 2016, Book 1, pp. 99-108.

[17] Sommer, Klaus-Dieter, Sarge,. S. M.: Energy measurement and standards - The contemporary challenge, 2 nd IMEKO TC 11 International Symposium Metrological Infrastructure, June 15-17, 2011, Cavtat, Dubrovnik, Croatia.

[18] Čundeva-Blajer, M., Dimčev, V., Srbinovska, M., Kokolanski, Ž.: A Contribution to the metrology infrastructure through accredited and traceable electrical measurements and calibrations, ETAI, 2016. 
